\title{
INVESTIGATION OF INTERMEDIARY WHEAT-AGROPYRON HYBRIDS ON RESISTANCE TO LEAF RUST
}

\author{
P.Yu. Krupin', M.G. Divashuk1, V.I. Belov², A.I. Zhemchuzhina ${ }^{3}$, E.D. Kovalenko ${ }^{3}$, \\ V.P. Upelniek ${ }^{2,}$, G.I. Karlov1 \\ ${ }^{1}$ Center of Molecular Biotechnology, Russian State Agratian University-Moscow Timiryazev Agricultural Academy, Moscow 127550, Russia \\ e-mail: pavelkroupin@gmail.com,divashuk@gmail.com,karlov@timacad.ru \\ ${ }^{2}$ Tsitsin Main Botanical Garden, RAAS, Moscow 127276, Russia \\ e-mail:nex_snegiri@mail.ru \\ ${ }^{3}$ All-Russia Research and Development Institute of Phytopathology, RAAS, \\ Bolshye Viazemy settlement 143050, Odintsovo district, Moscow province, Russia \\ e-mail: zhemchuzhina@vniif.ru,kovalenko@vniif.ru \\ ${ }^{4}$ Vavilov Institute of General Genetics, RAS, Moscow 119991, Russia \\ e-mail: vla-upelniek@yandex.ru
}

Received August 19, 2012

$\mathrm{S}$ u $\mathrm{m}$ m a r y

The estimation was made for 18 variants of octaploid winter wheat-Agropyron hybrids (WAH) $(2 n=56)$ on juvenile resistance to 10 isolates of leaf rust. By the use of molecular markers the presence of different subgenomes of Thinopyrum sp. in investigated variants was shown. In variants of WAH the authors revealed a polymorphism on resistance to test-isolates of leaf rust, which may be due to various number of agropyron chromosomes in genome. The authors discussed the possibility of using studied WAH in breeding on resistance to leaf rust and the role of resistance in improvement of economical-valued determinants of WAH in breeding process.

Keywords: wheat, wheat-Thinopyrum hybrids, leaf rust, resistance genes.

Leaf rust (Puccinia triticina Eriks.) is the cause of a significant damage to wheat (crop loss up to $50 \%$ ), especially in southern regions of Russia (1). Over 50 genes for rust resistance have been detected (2), and molecular markers have been developed for many of these genes (3). Very often sources of such genes are wild relatives of wheat. In particular, genes $L r 24, L r 29$, and $L r 19$ of Thinopyrum ponticum (genomic constitution JJJJsJs, $2 n=70$ ) and Lr38 gene of Th. intermedium (genomic constitution JSJs, $2 n=42$ ) were transferred into wheat through intergeneric hybridization in order to provide its resistance to many races of the pathogen (4). The emergence and spread of new races weakens the resistance caused by these genes (5-7), that's why it is important to find new genes for complete or partial resistance to leaf rust of wheat that will help to develop a pyramidal system of cultivars' resistance. Besides, introduction of new genes to commercial wheat varieties through hybridization will retard host-parasite co-evolution.

Hybrids of wheat and Agropyron (Th. intermedium) are seen as a promising source of new genes for rust resistance. In this regard, there's a great potential in the collection of wheat-Agropyron hybrids (WAH) developed in the Department of distant hybridization of Tsitsin Main Botanical Garden (RAS) by crosses of wheat (both soft and durum) with different Agropyron species (including intermediate and tall wheat grass). These hybrids have long loose ear typical for perennial wheat and manifest various types of perennial life cycle and regrowth after mowing. Earlier the authors have shown octaploid $(2 n=56)$ nature of these plants $(8)$.

One of important steps in creation of new resistant wheat forms is immunological evaluation (9). The abovementioned WAH weren't subject to phytopathological analysis, and relative resistance of these forms was evaluated only in field observations, which are strongly influenced by the environment (10).

The purpose of this work was screening of the collection of winter wheat-Thynopyrum hybrids for the presence of Thynopyrum genome and leaf rust resistance.

Technique. The studied samples were winter WAH Istra 1, Zernokormovaya 169, Ostankinskaya, Otrastayuschaya $38,{ }^{11} 12$, 33, 77, 90, 116, 186, 548, 1405, 1670, 2087, 4015, 4044, 4082, 5542 (Department of distant hybridization of Tsitsin Main Botanical Garden of RAS) derived through stepwise crosses between soft and durum (samples ${ }^{1} 33$ and ${ }^{1}$ 90) wheat Triticum aestivum, Thynopyrum intermedium, and Thynopyrum ponticum. In PCR, intermediate wheatgrass (sample PI 401200, GRIN) and Elytrigia elongata (sample PI 547312, GRIN) served as a control, the negative control was soft wheat cultivar Chinese Spring.

DNA for PCR was extracted from etiolated seedlings using CTAB-protocol according to R. Bernatzky and S.D. Tanksley (11). The used markers of wheat grass genome were RAPD-marker OPN01 (12) specific to S-subgenome and SCAR-markers F03 (13) and ple2 (14) specific to J-subgenome. Conditions of amplification are shown in Table 1. The resulting fragments were separated in $1,5 \%$ agarose gel at a field strength of $6 \mathrm{~V} / \mathrm{cm}$.

\section{Forward $(F)$ and reverse $(\mathrm{R})$ primers, PCR protocol and expected amplicon size for} markers specific to subgenomes of Agropyron

\begin{tabular}{|c|c|}
\hline Pair of primers / primer & Regime of amplification \\
\hline \multicolumn{2}{|c|}{ M a r k e r F 03 (expected amplicon size $-1270 \mathrm{bp}$ ) } \\
\hline F 5'-TGATCACCTGGTTGATAAGTCA-3' & 1 cycle $-94^{\circ} \mathrm{C} 3 \mathrm{~min} ; 20$ cycles $-94{ }^{\circ} \mathrm{C} 45 \mathrm{sec}, 58^{\circ} \mathrm{C} 30 \mathrm{sec}, 72{ }^{\circ} \mathrm{C}$ \\
\hline R 5'-AAAGTATTTATTCACTCAACCGGATCT-3' & $60 \mathrm{sec} ; 1 \mathrm{cycle}-72{ }^{\circ} \mathrm{C} 10 \mathrm{~min}$ \\
\hline \multicolumn{2}{|c|}{ M a r k e r O P N 01 (expected amplicon size - 817 bp) } \\
\hline $5^{\prime}$-CTCACGTTGG-3' & $\begin{array}{l}1 \text { cycle }-94{ }^{\circ} \mathrm{C} 4 \mathrm{~min} ; 5 \text { cycles }-92{ }^{\circ} \mathrm{C} 30 \mathrm{~s}, 35^{\circ} \mathrm{C} 2 \mathrm{~min}, 72{ }^{\circ} \mathrm{C} 90 \\
\text { sec; } 35 \text { cycles }-92{ }^{\circ} \mathrm{C} 5 \mathrm{sec}, 40{ }^{\circ} \mathrm{C} 20 \mathrm{sec}, 92^{\circ} \mathrm{C} 90 \mathrm{sec} ; 1 \mathrm{cycle}- \\
72{ }^{\circ} \mathrm{C} 5 \mathrm{~min}\end{array}$ \\
\hline \multicolumn{2}{|c|}{ M a r k e r p le 2 (expected amplicon size $-250 \mathrm{bp})$} \\
\hline F 5'-ACAATCTGAAAATCTGGACA-3' & 1 cycle $-94^{\circ} \mathrm{C} 4 \mathrm{~min} ; 28$ cycles $-94^{\circ} \mathrm{C} 60 \mathrm{sec}, 60^{\circ} \mathrm{C} 60 \mathrm{sec}, 72^{\circ} \mathrm{C} 2$ \\
\hline R 5'-TCATATTGAGACTCCTATAA-3' & $\min ; 1$ cycle $-72^{\circ} \mathrm{C} 10 \mathrm{~min}$. \\
\hline
\end{tabular}

To study the resistance to leaf rust, 5-day-old seedlings were inoculated with urediniospores of test isolates, then placed in a moist chamber for 16-20 h, and then transferred into a climate chamber PGV-36 ("Thermo Fisher Scientific", Australia) (air 
temperature $+20{ }^{\circ} \mathrm{C}$, relative humidity $60-70 \%$, illumination $10-15$ thousand $1 \mathrm{x}$, photoperiod $16 \mathrm{~h}$ ); the response of samples and monogenic lines was evaluated on the $10^{\text {th }}$ day.

Results. Resistance to 10 isolates of leaf rust Puccinia triticina Eriks. (Table 2) was studied in 16 WAH samples.

2. Characteristics of Puccinia triticina Eriks. isolates used for inoculation

\begin{tabular}{|c|c|c|}
\hline Isolates & Composition of virulence genes & \begin{tabular}{|l}
$\begin{array}{l}\text { Origin of isolate } \\
\text { (year, region, cultivar) }\end{array}$ \\
\end{tabular} \\
\hline $550-4$ & $\begin{array}{l}1,2 a, 2 b, 2 c, 3 a, 3 b g, 11,14 a, 17,18,20,21,25,30,32,33,39,40, \\
\text { B }\end{array}$ & $\begin{array}{l}\text { 2005, Low Volga, } \\
\text { Viktoriya } 95 \text { (winter cv) }\end{array}$ \\
\hline $555-6$ & $\begin{array}{l}1,2 a, 2 b, 2 c, 3 a, 3 b g, 3 \mathrm{ka}, 10,14 a, 14 b, 17,18,23,25,26,27+31 \text {, } \\
30,32,33,40, \mathrm{~B}\end{array}$ & $\begin{array}{l}2005 \text {, North Caucasus, } \\
\text { Rostovchanka (winter cv) }\end{array}$ \\
\hline $558-3$ & $\begin{array}{l}1,2 a, 2 b, 2 c, 3 a, 3 b g, 3 \mathrm{ka}, 10,11,14 a, 14 b, 17,18,19,20,21,23, \\
25,26,27+31,30,32,33,39,40,44,46, \mathrm{~B}\end{array}$ & $\begin{array}{l}\text { 2005, Center of Russia, } \\
\text { Obskaya } 14 \text { (spring cv) }\end{array}$ \\
\hline $681-13$ & $\begin{array}{l}1,2 a, 2 b, 2 c, 3 a, 3 b g, 3 k a, 10,14 a, 17,18,19,20,23,25,30,32, \\
33,39,40, \mathrm{~B}\end{array}$ & $\begin{array}{l}\text { 2008, Western Siberia, } \\
\text { Tertsiya (spring cv) }\end{array}$ \\
\hline $687-5$ & $\begin{array}{l}1,2 a, 2 b, 2 c, 3 a, 3 b g, 3 k a, 10,14 a, 14 b, 17,18,20,23,25,26,30, \\
32,33,39,40, \mathrm{~B}\end{array}$ & $\begin{array}{l}\text { 2008, North Caucasus, } \\
\text { Triticale (winter cv) }\end{array}$ \\
\hline $689-5$ & $\begin{array}{l}1,2 a, 2 b, 2 c, 3 a, 3 b g, 3 k a, 10,11,14 a, 14 b, 16,17,18,19,20,21, \\
23,25,26,27+31,30,33,39,40, \mathrm{~B}\end{array}$ & $\begin{array}{l}\text { 2008, North Caucasus, } \\
\text { Michigan Amber (winter cv) }\end{array}$ \\
\hline $693-5$ & $\begin{array}{l}1,2 a, 2 b, 2 c, 3 a, 3 b g, 3 k a, 10,11,14 a, 14 b, 15,16,17,18,20,23, \\
25,26,30,32,33,39,40, \mathrm{~B}\end{array}$ & $\begin{array}{l}\text { 2008, North Caucasus, } \\
\text { Krasnodarskaya } 99 \text { (winter cv) }\end{array}$ \\
\hline $698-1$ & $\begin{array}{l}1,2 a, 2 b, 2 c, 3 a, 3 b g, 3 k a, 10,11,14 a, 14 b, 15,16,17,18,19,21, \\
25,26,30,32,33,39,44, \mathrm{~B}\end{array}$ & $\begin{array}{l}\text { 2008, Central Chernozem, } \\
\text { Volzhskaya } 100 \text { (winter cv) }\end{array}$ \\
\hline $702-5$ & $\begin{array}{l}1,2 a, 2 b, 2 c, 3 a, 3 b g, 3 \mathrm{ka}, 10,11,14 a, 14 b, 16,17,18,20,21,23, \\
25,26,30,32,33,36,39,40, \mathrm{~B}\end{array}$ & $\begin{array}{l}\text { 2008, Central Chernozem, } \\
\text { Moskovskaya } 39 \text { (winter cv) }\end{array}$ \\
\hline $717-2$ & $\begin{array}{l}1,2 a, 2 b, 2 c, 3 a, 3 b g, 3 \mathrm{ka}, 10,11,14 a, 16,17,18,19,20,21,23, \\
25,26,27+31,30,32,33,39,40, \mathrm{~B}\end{array}$ & $\begin{array}{l}\text { 2008, Middle Volga, } \\
\text { Smuglyanka (winter cv) }\end{array}$ \\
\hline
\end{tabular}

3. Presence ("+") or absence ("-") of response in wheat-Agropyron hybrids inoculated with Puccinia triticina Eriks. isolates

\begin{tabular}{l|c|c|c|c|c|c|c|c|c|c}
\hline \multirow{2}{*}{ Sample, cultivar } & \multicolumn{9}{c}{ Pathogen isolate } \\
\cline { 2 - 9 } & $558-3$ & $693-5$ & $698-1$ & $687-5$ & $681-13$ & $550-4$ & $555-6$ & $702-5$ & $717-2$ & $689-5$ \\
\hline${ }^{1} 12$ & + & + & - & + & + & + & + & + & + & + \\
${ }^{1} 33$ & + & + & + & + & + & + & + & - & + & + \\
${ }^{1} 77$ & - & - & - & - & - & - & - & - & - & - \\
${ }^{1} 90$ & - & - & - & - & - & - & - & - & - & - \\
${ }^{1} 116$ & - & + & - & - & - & - & - & - & + & + \\
${ }^{1} 186$ & + & - & + & - & - & - & - & + & - & - \\
${ }^{1} 548$ & - & - & - & - & - & - & - & - & - & - \\
${ }^{1} 1405$ & - & - & - & - & - & - & - & - & - & - \\
${ }^{1} 1670$ & - & - & + & + & - & - & + & + & - & + \\
${ }^{1} 2087$ & - & - & - & - & - & - & - & - & - & - \\
${ }^{1} 4015$ & - & - & - & - & - & - & - & - & - & - \\
${ }^{1} 4044$ & - & + & + & - & - & - & - & - & - & - \\
${ }^{1} 4082$ & + & + & + & + & + & - & + & + & + & + \\
${ }^{1} 5542$ & + & + & + & + & - & - & - & + & - & - \\
Ostankinskaya & - & - & - & + & - & - & - & + & - & - \\
Istra 1 & - & - & - & - & - & - & - & - & - \\
Otrastayuschaya 38 & + & + & + & - & + & - & + & + & + \\
Zernokormovaya 169 & - & + & - & - & - & + & + & - & - \\
Chinese Spring & + & + & + & + & + & + & + & + & + \\
\hline
\end{tabular}

According to results of this test, all WAH were separated to three groups: immune to all isolates (№№ 77, 90, 548, 1405, 2087, 4015, cv Istra 1), susceptible to 1-5 isolates (№№ 116, 186, 1670, 4044, 5542, cv Ostankinskaya, Zernokormovaya 169), and susceptible to more than 5 isolates (№№ 12, 33, 4082, cv Otrastayuschaya 38). The variety Chinese Spring not carrying Lr-genes for juvenile resistance was totally susceptible to all the isolates. Pathotypes derived from different regions of the RF notably varied in virulence (15). Samples of the first and second groups can be recommended as a promising source of new resistance genes for a broad-spectrum resistance to pathotypes prevailing in the territory of Russia, while the third group can be used in breeding for resistance only locally with respect to occurrence of the isolate to which the line manifested resistance.

Previously, the authors have established chromosomal set of the studied samples that carry 56 chromosomes in octaploid genome (16). Using genomic hybridization in situ, the karyotype of octaploid WAH was determined as 42 chromosomes of wheat and 14 chromosomes of wheat grass (16), although there may be deviations from these values (17).

Subgenomic composition of the studied WAH samples was established by PCR with specific markers for subgenomes of polyploid Agropyron species used in breeding (intermediate wheat grass - JSJs, tall wheat grass - JJJJsJs). Using the markers F03 and ple2 specific to J-subgenome, amplification product was obtained in all the lines, for the marker OPN01 specific to S-subgenome - in all lines except the line № 116 (Fig. ) . 


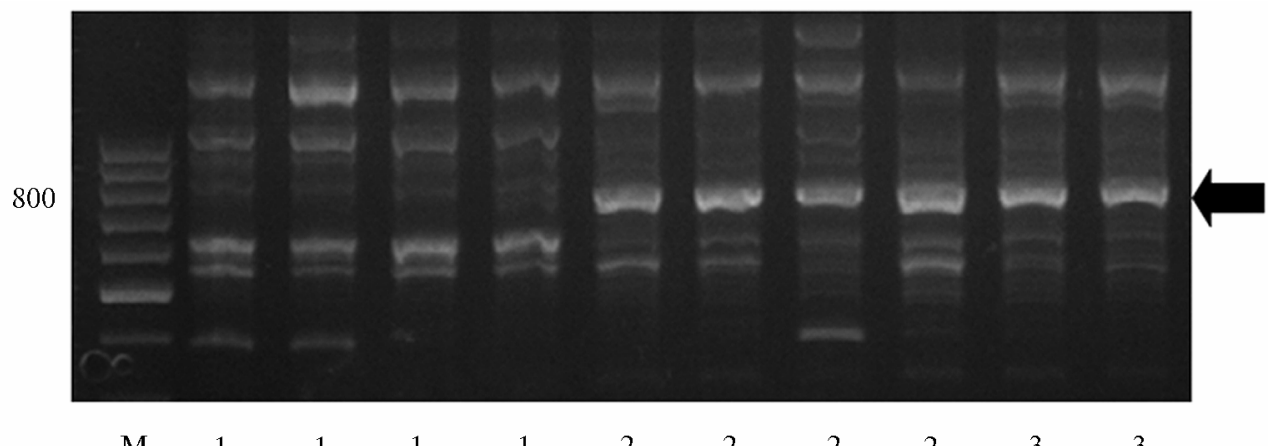

$\begin{array}{lllllllllll}M & 1 & 1 & 1 & 1 & 2 & 2 & 2 & 2 & 3 & 3\end{array}$

Illustration of absence (1 - WAH № 5787) and presence $(2-$ WAH № 1754, 3 - WAH № 1867) of amplification on the target band ( $817 \mathrm{bp})$ with OPN01 marker for S-subgenome of Agropyron.

M - molecular weight marker Gene Ruler 100 bp ('Fermentas”, Lithuania).

So, all the tested samples (except № 116) carry in their genomes the wheat grass chromosomes belonging to different subgenomes $\left(\mathrm{S}, \mathrm{J}\right.$, and $\mathrm{J}^{\mathrm{S}}$ ), while the sample № 116 doesn’t carry any chromosomes of S-subgenome.

Previously, differences in chromosomal sets of wheat grass cultivars Istra 1, Zernokormovaya 169, Ostankinskaya, and Otrastayuschaya 38 were revealed by the authors using GISH method (16). The presented work shows differences of these four samples in the level of resistance to leaf rust. It can be logically assumed that polymorphism of rust resistance in these WAH is associated with peculiarities of their genomes. Other tested WAH samples manifested variation in rust resistance, as well as genomic composition (based on amplification of PCR-markers). These data allow a conclusion that level of rust resistance of these samples depends on the combination of wheat grass chromosomes from different subgenomes.

In experiments of other authors, resistance to leaf rust was studied only in cv Otrastayuschaya 38 and evaluated as 2 on a 4point scale (0 - immunity) (18). In this work, Otrastayuschaya 38 also exhibited partial resistance (only to 3 isolates). Long-term field observations of cultivars Ostankinskaya, Istra 1, and Zernokormovaya 169 revealed a broad-spectrum resistance to many diseases including leaf rust (10). In the authors' test, cv Istra 1 showed immunity to all the isolates, cv Zernokormovaya 169 and Ostankinskaya showed susceptibility to, respectively, three and two isolates. Cv Istra 1, Ostankinskaya, and Zernokormovaya 169 were established later than cv Otrastayuschaya 38, and they demonstrate higher yield of green mass and grain yield (10). These features can be improved by increasing the resistance to leaf rust.

Thus, the earlier developed molecular markers of wheat grass chromosomes for four abovementioned cultivars, and molecular-cytogenetic studies performed on the rest of wheat-Agropyron hybrids (WAH), along with phytopathological estimates can be used for mapping the leaf rust resistance genes and the development of their molecular markers. A promising use of such markers is target introgression of new Lr-genes of wheat grass from WAH into soft wheat, which allows creating new resistant lines and varieties.

\section{REFERENCES}

1. McIntosh R.A., Wellings C.R., Park R.F. Wheat rusts: An atlas of resistance genes. Melbourne, Australia: Australian Commonwealth Scientific and Research Organization (CSIRO), 1995.

2. McIntosh R.A. From Farrer to the Australian cereal rust control program. Austr. J. Agr. Res., 2007, 58: 550-557.

3. Tyryshkin L.G. Sel'skokhozyaistvennaya Biologiya [Agricultural Biology], 2010, 3: 76-81.

4. Li H., Wang X. Thinopyrum ponticum and Th. intermedium: the promising source of resistance to fungal and viral diseases of wheat. J. Genet. Genomics, 2009, 36: $557-565$.

5. Bhardwaj S.C., Prashar M., Kumar S., Jain S.K., Datta D. Lr19 resistance in wheat becomes susceptible to Puccinia triticina in India. Plant Dis., 2005, 89: 1360.

6. Elyasi-Gomari S., Panteleev V.K. Virulence polymorphism of Puccinia recondita f. sp. tritici and effectiveness of Lr genes for leaf rust resistance of wheat in Ukraine. Plant Dis., 2006, 90: 853-857.

7. Morgounov A., Ablova I., Babayants O., Babayants L., Bespalova L., Khudokormov Zh., Litvinenko N., Shamanin V., Syukov V. Genetic protection of wheat from rusts and development of resistant varieties in Russia and Ukraine. Euphytica, 2011, 179: 297-311.

8. Krupin P.Yu., Divashuk M.G., Belov V.I., Semenova E.V., Artamonov V.D., Karlov G.I. Estestvennye i Tekhnicheskie Nauki, $2011,6: 123-126$.

9. Kovalenko E.D., Makarov A.A., Zhemchuzhina A.I., Kolomiets T.M., Solomatin D.A., Kiseleva M.I. Materialy Vserossiiskogo soveshchaniya «Sovremennye sistemy zashchity rastenii ot boleznei i perspektivy ispol'zovaniya dostizhenii biotekhnologii igennoi inzhenerii» [Proc. All-Russia Conference «Modern Systems of Crop Protection from Diseases and Prospects for Practical Use of the Achievements of Biotechnology and Gene Technology»]. Golitsino, 2003: 52-54.

10. Belov V.I., Ivanova L.P. Otdalennaya gibridizatsiya. Rezul'taty issledovaniya /Pod redaktsiei V.I. Semenova [Distant Hybridization. Results of Investigation. V.I. Semenov (ed.)]. M., 2001: 166-177.

11. Bernatzky R., Tanksley S.D. Toward a saturated linkage map in tomato based on isozymes and random cDNA sequences. Genetics, $1986,112: 887-898$.

12. Zhang X., Dong Y., Wang R.R. Characterization of genomes and chromosomes in partial amphiploids of the hybrid Triticum aestivum $\times$ Thinopyrum ponticum by in situ hybridization, isozyme analysis, and RAPD. Genome, 1996, 39: 1062-1071.

13. Li H., Wang X. Thinopyrum ponticum and Th. intermedium: the promising source of resistance to fungal and viral diseases of wheat. J. Genet. Genomics, 2009 , 36: 557-565.

14. Wang R.R., Wei J.Z. Variations of two repetitive DNA sequences in several Triticeae genomes revealed by polymerase chain reaction and sequencing. Genome, 1995, 38: $1221-1229$

15. Kiseleva M.I., Kovalenko E.D., Zhemchuzhina A.I., Kurkova N.N. AGRO XXI, 2004-2005, 7-12: 25-29.

16. Krupin P.Yu., Divashuk M.G., Belov V.I., Glukhova L.I., Aleksandrov O.S., Karlov G.I. Genetika, 2011, 47: 492-498.

17. Fedak G., Han F. Characterization of derivatives from wheat-Thinopyrum wide crosses. Cytogenet. Genome Res., 2005 , 109: $360-367$.

18. Banks P.M., Xu S.J., Wang R.R., Larkin P.J. Varying chromosome composition of 56-chromosome wheat $\times$ Thinopyrum intermedium partial amphiploids. Genome, 1993, 36: 207-215. 